\title{
Prokrastinasi Ditinjau Dari Gaya Kepemimpinan Transformasional Dan Self Efficacy
}

\author{
Dwi Rio Sudarroji, Fahmawanti Sekaringrum, Leo Trihartantyo \\ Pascasarjana Magister Psikologi Profesi, Universitas Ahmad Dahlan Yogyakarta \\ Email: dwiriosudarroji@gmail.com, fahmasekar2@gmail.com, leotrihartantyo@gmail.com
}

\begin{abstract}
This study was conducted to determine the relationship between leadership style and self-efficacy on procrastination. The study population amounted to 34 teachers in a public school in Yogyakarta. The analytical method was a multiple linear regression. Data collection devices are a questionnaire scale of procrastination, self-efficacy, and leadership style. The result showed that correlation significant between self-efficacy and leadership style to procrastination was $p=0.007<0.05$ and a correlation coefficient was $B=0.015$ to variable leadership style and a correlation coefficient was $B=-0.548$ to variable self-efficacy. It showed that there is a positive correlation between leadership style and procrastination but just small influence and a negative correlation between self-efficacy and procrastination.
\end{abstract}

Keywords: Procrastination, Self-efficacy, Leadership Style

\begin{abstract}
Abstrak
Penelitian ini dilakukan untuk mengetahui hubungan gaya kepemimpinan dan self-efficacy terhadap prokrastinasi. Populasi penelitian berjumlah 34 guru di salah satu sekolah negeri di Yogyakarta. Data analisis dengan regresi linier berganda. Alat pengumpulan data berupa kuesioner skala prokrastinasi, self-efficacy, dan gaya kepemimpinan. Hasil penelitian ini menunjukkan bahwa variabel gaya kepemimpinan dan self-efficacy memiliki hubungan terhadap prokrastinasi. Variabel gaya kepemimpinan dan self-efficacy terhadap prokrastinasi memiliki nilai signifikansi sebesar $\mathrm{p}=0,007<0,05$ dan nilai koefisien korelasi $\mathrm{B}=0,015$ untuk variabel gaya kepemimpinan, dan nilai koefisien korelasi $\mathrm{B}=-0,543$. Hal tersebut menunjukkan adanya hubungan positif antara gaya kepemimpinan terhadap prokrastinasi namun kecil pengaruhnya, dan ada hubungan negatif antara self-efficacy dengan prokrastinasi.
\end{abstract}

Kata kunci: Prokrastinasi, Self-efficacy, Gaya Kepemimpinan.

\section{Pendahuluan}

Tugas merupakan salah satu tuntutan dalam sebuah pekerjaan yang harus diselesaikan dalam batasan waktu tertentu. Saat mengerjakan tugas setiap individu memiliki kemampuan yang berbeda-beda, ada individu yang cenderung dengan cepat menyelesaikan tugasnya ada juga yang cenderung menunda untuk menyelesaikan tugasnya. Oleh karena itu, perilaku yang tidak efisien dalam menggunakan waktu dan adanya kecenderungan untuk tidak segera memulai suatu pekerjaan ketika menghadapi suatu tugas disebut dengan prokrastinasi (Ghufron dan Rini, 2010). Menurut Kurniawati dan Astuti (2008), jika seseorang pegawai melakukan prokrastinasi atau penundaan dalam pekerjaannya, maka akan timbul masalah dalam pekerjaan yang mereka tunda. Pekerjaan pegawai tersebut akan terus menumpuk sehingga semakin terbebani dengan pekerjaan tersebut. Mereka akan dikejar batas waktu penyelesaian pekerjaan dengan target yang harus dipenuhi, padahal pekerjaan tersebut tertunda. Hasil penelitian yang dilakukan oleh Tamin tahun 2000 dari seluruh Pegawai Negeri Sipil yang ada di Indonesia hanya 40\% saja yang benar-benar profesional. Melihat pada kondisi atau kenyataan sekarang di kantor-kantor instansi pemerintah, misalnya kantor kelurahan dan dinas masih terlihat banyak pegawai yang tidak optimal dalam mengerjakan tugasnya pada saat jam kerja kantor. Hal ini tampak dari perilaku yang ditampilkan seperti membaca koran atau majalah, bercakap-cakap dengan rekannya sambil merokok, pergi ke kedai kopi di waktu jam kerja bukan untuk alasan dinas. Kondisi tersebut menggambarkan bahwa di kantor pemerintah banyak para pegawai yang relatif sering melakukan prokrastinasi kerja sehingga sangat merugikan masyarakat yang sebenarnya sangat membutuhkan pelayanan jasa dengan cepat.(kompasiana, 26/06/15). Berdasarkan hasil wawancara pada tiga orang guru disalah satu sekolah negeri mendapatkan data bahwa terdapat beberapa guru yang melakukan penundaan pada pekerjaan yang diberikan. Guru sering menunda pekerjaan mereka hingga batas waktu yang diberikan. Salah satu contoh yaitu tugas membuat laporan administrasi pekerjaan guru. Tugas tersebut seharusnya di laporan setiap seminggu sekali, tetapi banyak guru yang tidak mengumpulkan laporan tersebut secara tepat

Diterima Redaksi : 02-05-2020 | Selesai Revisi : 16-05-2020 | Diterbitkan Online : 01-06-2020 
waktu. Menurut Burka dkk (dalam Ghufron dan Rini, 2010), menyatakan bahwa prokrastinator memandang tugas sebagai sesuatu yang berat dan tidak menyenangkan. Oleh karena itu, seseorang merasa tidak mampu menyelesaikan tugasnya secara memadai sehingga menunda-nunda menyelesaikan tugas tersebut. Menghadapi penyebab prokrastinasi tersebut diperlukan keyakinan akan kemampuannya untuk menghadapi permasalahan dan melakukan tindakan yang dibutuhkan dalam menyelesaikan tugas untuk menghadapi hasil yang diharapkan. Keyakinan seseorang akan kemampuan yang dimiliki berdasarkan Bandura di sebut dengan istilah self-efficacy. Seperti yang dikatakan Steel (2007) bahwa self-efficacy memiliki peranan cukup penting dalam kemunculan prokrastinasi. Keinginan melakukan sesuatu hal akan menjadi tinggi ketika harapan keberhasilan juga tinggi. Sehingga tingkat prokrastinasi akan menjadi rendah (Steel, 2007). Selain itu gaya kepemimpinan transformasional merupakan faktor penentu yang mempengaruhi sikap, persepsi, dan perilaku karyawan di mana terjadi peningkatan kepercayaan kepada pemimpin, motivasi dan kepuasan kerja serta mampu mengurangi sejumlah konflik yang sering terjadi dalam suatu organisasi (Yukl, 1998). Menurut Burn dalam (Marselius dan Rita, 2004) gaya kepemimpinan transformasional mampu menurunkan prokrastinasi kerja bagi karyawan karena kebutuhan karyawan yang lebih tinggi seperti kebutuhan harga diri dan aktualisasi diri terpenuhi. Berdasarkan permasalahan dan kerangka pemikiran, maka peneliti tertarik untuk meneliti lebih lanjut terhadap hubungan antara gaya kepemimpinan transformasional dan self-efficacy terhadap prokrastinasi pada guru SMP N 1 Kretek.

\section{Prokrastinasi}

Prokrastinasi (kecenderungan untuk menunda ketika menghadapitugas atau tidak segera menyelesaikan tugas yang dimiliki) pada dasarnya berasal dari dua bahasa latin yaitu "pro" yang berarti motivasi mendorong untuk bergerak maju dan "crastinus" berarti untuk hari esok (Ferrari,Johnson \& McCown, 1995). Prokrastinasi terbagi menjadi dua jenis yaitu prokrastinasi akademik dan prokrastinasi nonakademik. Prokrastinasi akademik adalah penundaan tugas yang dilakukan oleh seseorang dalam hal akademik (Ferrari, Johnson \&McCown, 1995).

Faktor yang mempengaruhi prokrastinasi akademik yaitu faktor internal dan faktor eksternal. Faktor internal merupakan pengaruh prokrastinasi yang didapat dari dalam diri individu itu sendiri, sedangkan faktor eksternal yaitu pengaruh prokrastinasi didapat dari luar individu misalnya pengasuhan orangtua dan lingkungan. Faktor internal yang mempengaruhi prokrastinasi akademik dalam diri individu antara lain kondisi fisik seperti kelelahan, dan kondisi psikologis seperti keraguan dan motivasi (Ferrari, Johnson \& McCown, 1995).

Van Eerde menyatakan faktor-faktor yang berkorelasi dengan prokrastinasi adalah sebagai berikut: a) Demographic, Usia, jenis klamin, atau pendidikan juga dapat berdampak pada penundaan, karena memiliki nilai-nilai dan juga pengalaman yang berbeda, b) Personality Variable, Perilaku individu berkaitan dengan sejumlah penundaan, individu yang memiliki kesadaran yang rendah akan cenderung menunda-nunda pekerjaan. Individu yang tinggi neurotis nya juga cendrung menunda-nunda tugas, c) Self-image, Menunda tugas sangat berkaitan dengan harga diri yang rendah, d) Motives, Perfeksionis dan takut gagal telah dijadikan alasan sebagai menghindari tugas-tugas. Penundaan dilakukan karena tidak ingin mendapatkan feedback yang negatif, e) Affect, Afeksi mempengaruhi prokrastinasi ketika ada hasil negatif psikologi seperti cemas atau depresi seseorang akan cendrung menunda tugas karena perasaan tersebut muncul, f) Performance, Penundaan dapat dipengaruhi oleh ketersediaan waktu pengerjaan tugas yang diberikan.

Ferrari \& McCown (1995) menyatakan aspek-aspek prokrastinasi meliputi: a) Perceived time, Seseorang yang cenderung prokrastinasi adalah orang-orang yang gagal menepati deadline. Mereka berorientasi pada masa sekarang dan tidak mempertimbangkan masa mendatang. Prokrastinator tahu bahwa tugas yang dihadapinya harus segera diselesaikan, tetapi ia menunda-nunda untuk mengerjakannya atau menunda menyelesaikannya jika ia sudah memulai pekerjaannya tersebut. Hal ini mengakibatkan individu tersebut gagal memprediksikan waktu yang dibutuhkan untuk mengerjakan tugas, b) Intention-action, Celah antara keinginan dan tindakan. Perbedaan antara keinginan dengan tindakan senyatanya ini terwujud pada kegagalan siswa dalam mengerjakan tugas akademik walaupun siswa tersebut punya keinginan untuk mengerjakannya. Ini terkait pula dengan kesenjangan waktu antara rencana dan kinerja aktual. Prokrastinator mempunyai kesulitan untuk melakukan sesuatu sesuai dengan batas waktu. Seorang siswa mungkin telah merencanakan untuk mulai mengerjakan tugasnya pada waktu yang telah ia tentukan sendiri, akan tetapi saat waktunya sudah tiba 
dia tidak juga melakukan sesuatu sesuai dengan apa yang telah ia rencanakan sehingga menyebabkan keterlambatan atau bahkan kegagalan dalam menyelesaikan tugas secara memadai, c) Emotional distress, Adanya perasaan cemas saat melakukan prokrastinasi. Perilaku menunda-nunda akan membawa perasaan tidak nyaman pada pelakunya. Konsekuensi negative yang ditimbulkan memicu kecemasan dalam diri pelaku prokrastinasi. Pada mulanya siswa tenang karena merasa waktu yang tersedia masih banyak. Tanpa terasa waktu sudah hampir habis, ini menjadikan mereka merasa cemas karena belum menyelesaikan tugas, d) Perceived ability, Atau keyakinan terhadap kemampuan diri. Walaupun prokrastinasi tidak berhubungan dengan kemampuan kognitif seseorang, namun keragu-raguan terhadap kemampuan dirinya dapat menyebabkan seseorang melakukan prokrastinasi. Hal ini ditambah dengan rasa takut akan gagal menyebabkan seseorang menyalahkan dirinya sebagai yang tidak mampu untuk menghindari munculnya dua perasaan tersebut.

\section{Self Efficacy}

Seseorang bertingkah laku dalam situasi tertentu pada umumnya dipengaruhi oleh faktor lingkungan dan kognitif, khususnya faktor kognitif yang berhubungan dengan keyakinan bahwa dirinya mampu atau tidak mampu melakukan tindakan yang memuaskan. Keyakinan atau yang disebut self-efficacy yang diungkapkan oleh Bandura (1997) yakni merupakan persepsi diri mengenai seberapa bagus diri dapat berfungsi dalam situasi tertentu. Self-efficacy juga merupakan penilaian diri, apakah dapat melakukan tindakan yang baik atau buruk, tepat atau salah, bisa atau tidak bisa mengerjakan sesuai dengan yang dipersyaratkan. Maka dapat dilihat bahwa self-efficacy menggambarkan penilaian kemampuan diri (Alwilsol, 2004).

Bandura (1997) mengemukakan beberapa dimensi self-efficacy, yakni sebagai berikut: a) Magnitude atau level yakni persepsi individu mengenai kemampuannya yang diukur melalui tingkat kesulitan dengan berbagai macam kesulitan tugas. Individu yang memiliki tingkat kesulitan tugas yang tinggi memiliki kekyakinan bahwa dirinya mampu mengerjakan tugas-tugas yang sukar dan juga memiliki self-efficacy yang tinggi, sedangkan individu dengan tingkat kesulitan tugas yang rendah memiliki keyakinan bahwa dirinya hanya mampu mengerjakan tugas-tugas yang mudah serta memiliki selfefficacy yang rendah, b) Generality, dimana individu menilai keyakinan mereka berada pada tingkat kesulitan tugas tertentu dalam arti luas individu mempunyai keyakinan dalam melaksanakan tugastugas. Generalisasi memiliki perbedaan dimensi yang bervariasi yaitu intensitas kesamaan aktivitas, kemampuan yang ditunjukkan dengan tingkah laku, kognitif, afektif. Menggambarkan secara nyata mengenai situasidan karakteristik perilaku individu yang ditunjukkan. Penilaian ini berkaitan dengan perilaku dan konteks situasi yang mengungkapkan keyakinan individu terhadap keberhasilan mereka, c) Strength, berkaitan dengan kuat-lemahnya keyakinan seorang individu. Individu yang memiliki keyakinan yang kuat akan bertahan dengan usaha mereka meskipun ada banyak kesulitan dan hambatan.

Gaya Kepemimpinan Transformational

Gaya kepemimpinan transformational adalah pemimpin yang membantu pengikutnya untuk mengatasi masalah mereka dan juga mampu memberikan dampak yang mendalam untuk pengikutnya (Robbin, 2012). Bass (1990) menjelaskan pengikut yang memiliki pemimpin bertipe transformasional akan merasa percaya, kagum loyal dan hormat kepada pemimpin dan mereka termotivasi untuk melakukan lebih daripada yang diharapka dari diri mereka.

Bass dan Avolio (1990) menyatakan ada 4I yang merepresentasikan transformational leadership, yakni, 1)Idealised influenced, Kekuatan pemimpin yang memiliki visi dan misi, yang mendapatkan rasa hormat, kepercayaan, dan keyakinan, dan yang memperoleh label pemimpin dari para pengikut. Pemimpin yang menunjukan pengaruh kuat akan mendapatkan usaha ekstra yang diberikan oleh pengikut, 2) Individually Considerate, Pemimpin dapat mendiagnosa kenutuhan dan kemampuan pengikut. Pemimpin tranformasional mendiagnosa kemudian hadir untuk pengikut secara personal. Pemimpin tranformasional juga melatih, memberikan saran, dan memberikan feedback kepada individu, 3) Intelectually Stimulating, Pemimpin memberikan motivasi agar pegawai dapat menyeselesaikan masalah dengan carayang baru. Meningkatkan pegawai untuk berpikir kreatif lalu merangsang pengikut untuk menggunakan intuisi serta logika yang lebih formal untuk memecahkan masalah. Pemimpin trasformasional mengajak pengikut untuk mengatasi masalah dengan perspektif yang unik dan inovatif, 
4) Inspirational, Pemimpin memberikan semangat, meningkatkan optimisme, antusiasme, dan dapat menyampaikan visi pemimpin mengenai harapan dan cita-cita secara lugas dan yakin. Pemimpin menyampaikan visi tersebut agar energi pengikut mencapai tingkat yang lebih tinggi sehingga dapat menghasilkan kinerja yang baik.

\section{Metode Penelitian}

Penelitian ini merupakan penelitian korelasional, yaitu penelitian yang bertujuan menyelidiki sejauhmana variasi pada satu variabel berkaitan dengan variasi pada satu atau lebih variabel lain, berdasarkan koefisien korelasi (Azwar, 2009). Penelitian ini dilakukan dengan metode pengambilan data menggunakan kuosioner yang melibatkan partisipan sejumlah 34 guru. Prosedur dalam penelitian ini adalah peneliti dating ke sekolah untuk meminta izin dan persetujuan dari pihak sekolah kemudian dilanjutkan dengan pengambilan data yaitu penyebaran skala. Subjek dalam penelitian ini adalah 34 guru SMP N 1 Kretek yang terdiri dari 20 orang guru perempuan dan 14 orang guru laki-laki. Metode pengambilan data menggunakan model random sampling dimana setiap individu dalam populasi mendapat kesempatan yang sama untuk menjadi partisipan atau subjek penelitian. Metode pengambilan data dalam penelitian ini menggunakan kuesioner yang didalamnya terdapat tiga skala untuk mengukur masing-masing variabel. Skala yang digunakan adalah skala prokrastinasi, skala gaya kepemimpinan transformasional, dan skala self-efficacy. Instrumen penelitian ini menggunakan skala model Likert, dimana terdapat 3-5 alternatif jawaban.

Skala prokrastinasi disusun berdasarkan teori Ferrari \& McCown (1995) yang terdiri dari empat aspek yaitu perceived time, intention-action, emotional distress, perceived ability. Pilihan dalam jawaban ini adalah sangat sesuai (SS), sesuai (S), tidak sesuai (TS), dan sangat tidak sesuai (STS). Pemberian skor pada masing-masing aitem dengan cara memberikan nilai 1 sampai 4. Untuk jawaban sangat sesuai (SS) diberi nilai 4, sesuai (S) diberi nilai 3, tidak sesuai (TS) diberi nilai 2, dan sangat tidak sesuai (STS) diberi nilai 1 dengan skor total yang diperoleh malai dari 10-40.

Skala gaya kepemimpinan tranformasional disusun berdasarkan teori Bass dan Avolio (1990) yang terdiri dari empat yaitu Idealised influenced, Individually Considerate, Intelectually Stimulating, Inspirational. Pilihan dalam jawaban ini adalah sangat sesuai (SS), sesuai (S), tidak sesuai (TS), dan sangat tidak sesuai (STS). Pemberian skor pada masing-masing aitem dengan cara memberikan nilai 1 sampai 4. Untuk jawaban sangat sesuai (SS) diberi nilai 4, sesuai (S) diberi nilai 3, tidak sesuai (TS) diberi nilai 2, dan sangat tidak sesuai (STS) diberi nilai 1 dengan skor total yang diperoleh mulai dari 10-40.

Skala self-efficacy (GSE) Schwarzer \& Jarusalem (1995) berjumlah 10 aitem yang merupakan skala unidimensional artinya 10 aitem telah mencakup didalamnya aspek magnitude, generality, dan strength. Skala disusun berdasarkan modifikasi model skala Likert yang dibuat dalam empat alternative yaitu sangat sesuai (SS), sesuai (S), tidak sesuai (TS), dan sangat tidak sesuai (STS). Pemberian skor pada masing-masing aitem dengan cara memberikan nilai 1 sampai 4. Untuk jawaban sangat sesuai (SS) diberi nilai 4, sesuai (S) diberi nilai 3, tidak sesuai (TS) diberi nilai 2, dan sangat tidak sesuai (STS) diberi nilai 1 dengan skor total yang diperoleh mulai dari 10-40. Analisis data dalam penelitian ini menggunakan analisis regresi ganda (multiple regretion) yaitu teknik statistik yang digunakan untuk menganalisis hubungan antara satu variabel dependen dan beberapa variabel bebas.(Sugiyono, 2003).

\section{Hasil dan Pembahasan}

Hasil dari analisis data pada variabel self efficacy, gaya kepemimpinan, dan prokrastinasi menghasilkan Cronbach's Alpha 0,781 dengan total aitem 10 aitem pada variabel self efficacy. Variabel gaya kepemimpinan menghasilkan Cronbach's Alpha 0,944 dengan total aitem 24. Sedangkan pada variabel prokrastinasi menghasilkan Cronbach's Alpha 0.820 dengan total aitem tersisa 10 aitem. Kemudian untuk menguji normalitas dan linearitas mendapatkan skor terbesar 0.191 untuk variable prokratinasi, 0,222 untuk variabel gaya kepemimpinan, dan 0,447 untuk variabel self efficacy. Berdasarkan tabel 1 dibawah terlihat bahwa ke tiga variabel memiliki nilai signifikan >0,05 sehingga dapat dikatakan bahwa ketiga variabel tersebut mempunyai sebaran data normal 
Dwi Rio Sudarroji, Fahmawanti Sekaringrum, Leo Trihartantyo

Psyche 165 Journal Vol 13 No 02 (2020) 246 - 252

Tabel 1. Uji Normalitas Tiga Variabel One-Sample Kolmogorov-Smirnov Test

\begin{tabular}{llrrrr}
\hline \multirow{2}{*}{$\mathrm{N}$} & & PK & GK & SE \\
\hline Normal Parameters ${ }^{\mathrm{a}, \mathrm{b}}$ & \multicolumn{1}{c}{ Mean } & 34 & 34 & 34 \\
\cline { 2 - 6 } & Std. Deviation & 23.8824 & 42.5294 & 29.2647 \\
\hline Most Extreme Differences & Absolute & 3.45328 & 7.15303 & 3.33311 \\
\cline { 2 - 6 } & Positive & .186 & .180 & .148 \\
\cline { 2 - 6 } & Negative & .095 & .180 & .148 \\
\hline Kolmogorov-Smirnov Z & & -.186 & -.164 & -.131 \\
\hline Asymp. Sig. (2-tailed) & & 1.083 & 1.048 & .862 \\
\hline
\end{tabular}

a. Test distribution is Normal.

b. Calculated from data.

Tabel 2. Uji Linearitas Gaya Kepemimpinan dan Self Efficacy Terhadap Prokrastinasi (Coefficients ${ }^{\mathrm{a}}$ )

\begin{tabular}{|c|c|c|c|c|c|c|c|c|}
\hline \multirow[b]{2}{*}{ Model } & & \multicolumn{2}{|c|}{$\begin{array}{c}\text { Unstandardized } \\
\text { Coefficients }\end{array}$} & \multirow{2}{*}{$\begin{array}{c}\text { Standardized } \\
\text { Coefficients }\end{array}$} & \multirow[b]{2}{*}{$\mathrm{t}$} & \multirow[b]{2}{*}{ Sig. } & \multicolumn{2}{|c|}{ Collinearity Statistics } \\
\hline & & B & Std. Error & & & & Tolerance & VIF \\
\hline \multirow[t]{3}{*}{1} & (Constant) & 38.827 & 5.879 & & 6.604 & .000 & & \\
\hline & $\begin{array}{l}\text { GAYA_KEP } \\
\text { EMIMPINA } \\
\mathrm{N} \\
\end{array}$ & .015 & .056 & .040 & .261 & .796 & .983 & 1.017 \\
\hline & $\begin{array}{l}\text { SELF_EFFIC } \\
\text { ACY }\end{array}$ & -.548 & .160 & -.529 & -3.432 & .002 & .983 & 1.017 \\
\hline
\end{tabular}

a. Dependent Variable: PROKRASTINASI

Berdasarkan perhitungan uji linearitas pada tabel 2 diatas, mendapatkan hasil bahwa variabel gaya kepemimpinan dan self-efficacy terhadap prokrastinasi linear yang ditunjukkan dengan nilai VIF $=$ 1,017. Variabel dinyatakan linier apabila nilai 3 <VIF> 1, maka dapat ditarik kesimpulan bahwa data menunjukkan ada hubungan antara gaya kepemimpinan dan self-efficacy terhadap prokrastinasi yang menyebabkan data dapat diteruskan ke uji regresi ganda.

Tabel 3. Analisis Regresi Ganda (ANOVA ${ }^{\mathrm{b}}$ )

\begin{tabular}{|c|c|c|c|c|c|c|}
\hline Model & & Sum of Squares & $\mathrm{df}$ & Mean Square & $\mathrm{F}$ & Sig. \\
\hline \multirow[t]{3}{*}{1} & Regression & 108.581 & 2 & 54.291 & 5.906 & $.007^{\mathrm{a}}$ \\
\hline & Residual & 284.948 & 31 & 9.192 & & \\
\hline & Total & 393.529 & 33 & & & \\
\hline
\end{tabular}

a. Predictors: (Constant), SELF_EFFICACY, GAYA_KEPEMIMPINAN

b. Dependent Variable: PROKRASTINASI

Berdasarkan uji regresi antara gaya kepemimpinan dan self-efficacy terhadap prokrastinasi pada tabel 3, mendapatkan hasil $\mathrm{F}$ sebesar 5,906 dan nilai signifikansi $=0,007<0,05$ yang berarti bahwa Ha diterima, yaitu terdapat hubungan antara variabel gaya kepemimpinan dan self-efficacy terhadap prokrastinasi.

Tabel 4 Analisis Tambahan (Coefficients ${ }^{a}$ )

\begin{tabular}{|c|c|c|c|c|c|c|c|c|}
\hline \multirow[b]{2}{*}{ Model } & & \multicolumn{2}{|c|}{$\begin{array}{l}\text { Unstandardized } \\
\text { Coefficients }\end{array}$} & \multirow{2}{*}{$\begin{array}{c}\text { Standardized } \\
\text { Coefficients } \\
\text { Beta }\end{array}$} & \multirow[b]{2}{*}{$\mathrm{t}$} & \multirow[b]{2}{*}{ Sig. } & \multicolumn{2}{|c|}{ Collinearity Statistics } \\
\hline & & $\mathrm{B}$ & Std. Error & & & & Tolerance & VIF \\
\hline \multirow[t]{3}{*}{1} & (Constant) & 38.827 & 5.879 & & 6.604 & .000 & & \\
\hline & $\begin{array}{l}\text { GAYA_K } \\
\text { EPEMIMP } \\
\text { INAN }\end{array}$ & .015 & .056 & .040 & .261 & .796 & .983 & 1.017 \\
\hline & $\begin{array}{l}\text { SELF_EFF } \\
\text { ICACY }\end{array}$ & -.548 & .160 & -.529 & -3.432 & .002 & .983 & 1.017 \\
\hline
\end{tabular}

a. Dependent Variable: PROKRASTINASI 
Berdasarkan tabel 4 menunjukkan nilai $\mathrm{B}=0,015$ yang berarti terdapat koefisien korelasi positif antara gaya kepemimpinan terhadap prokrastinasi namun sangat kecil pengaruhnya. Selanjutnya nilai B = 0,548 pada variabel self-efficacy yang berarti terdapat koefisien korelasi negatif antara kedua variabel, artinya adalah semakin tinggi self-efficacy yang dimiliki oleh guru maka akan semakin rendah prokrastinasi yang dilakukan, begitu juga sebaliknya semakin rendah self-efficacy yang dimiliki oleh guru makan akan semakin tinggi prokrastinasi yang dilakukan.

Tabel 5. Analisis Tambahan (Model Summary)

\begin{tabular}{lcccc}
\hline Model & R & R Square & Adjusted R Square & $\begin{array}{c}\text { Std. Error of the } \\
\text { Estimate }\end{array}$ \\
\hline 1 & $.525^{\text {a }}$ & .276 & .229 & 3.03181 \\
\hline a. Predictors: (Constant), SELF_EFFICACY, GAYA_KEPEMIMPINAN
\end{tabular}

Nilai $\mathrm{R}^{2}$ yang ditunjukkan sebesar 0,229 , artinya secara bersama-sama variabel gaya kepemimpinan dan self-efficacy memberikan sumbangsih sebesar $22,9 \%$ dalam menjelaskan variabel prokrastinasi, dan sisanya dipengaruhi oleh faktor lain.

Hasil penelitian ini menunjukkan bahwa self-efficacy berpengaruh secara negatif yang terbukti dengan nilai uji regresi sebesar $\mathrm{B}=-0,548$. Semakin tinggi self-efficacy yang dimiliki oleh guru maka akan semakin rendah prokrastinasi yang dilakukan, begitu juga sebaliknya semakin rendah self-efficacy yang dimiliki oleh guru makan akan semakin tinggi prokrastinasi yang dilakukan. Steel (dalam Lasmono, 2008) menyatakan bahwa prokrastinasi dipengaruhi oleh faktor perbedaan individu, salah satunya adalah self-efficacy. Menurut Bandura (dalam Rahardjo, 2011) menyatakan bahwa salah satu hal yang memengaruhi timbulnya prokrastinasi karyawan adalah self-efficacy. Self-efficacy adalah keyakinan yang dimiliki individu bahwa dirinya akan mampu menyelesaikan tugas-tugas tertentu hingga tuntas. Self-efficacy banyak berperan dalam pencapaian tujuan dan kinerja individu dalam dunia kerja. Salah satu proses yang mempengaruhi self-efficacy adalah proses kognitif. Mayoritas tindakan manusia bermula dari sesuatu yang difikirkan terlebih dahulu. Individu yang memiliki self-efficacy tinggi akan lebih senang membayangkan tentang kesuksesan. Sebaliknya individu yang memiliki self-efficacy rendah akan lebih banyak membayangkan kegagalan dan hal-hal yang dapat menghambat tercapainya kesuksesan dan menganggap hal-hal tersebut merupakan hal yang sulit diselesaikan. Seorang guru yang memiliki self-efficacy tinggi akan mampu mengerjakan berbagai tugas yang sulit sekalipun dengan tidak menunda-nunda tugas tersebut (Bandura, 1997).

Self-efficacy dapat menjadikan guru terhindar dari prokrastinasi kerja yang dapat merugikan sekolah pada umumnya dan juga diri sendiri. Hasil penelitian ini sejalan dengan hasil penelitian yang dilakukan Sawitri (2009) yang menunjukkan bahwa individu dengan self-efficacy akan berusaha melakukan penilaian diri, pencarian informasi, melakukan pemilihan, membuat perencanaan, dan memecahkan masalah. Self-efficacy akan membantu individu dalam membuat suatu keputusan. Self-efficacy pada guru akan membantu dalam menyelesaikan tugas dengan baik tanpa harus menunjukkan prokrastinasi kerja yang dapat merugikan diri sendiri dan instansi sekolah pada umumnya. Hasil penelitian yang dilakukan Muhid (2008) menunjukkan bahwa terdapat hubungan yang signifikan antara self-efficacy dengan kecenderungan prokrastinasi. Individu yang memiliki self-efficacy tinggi akan selalu mencoba melakukan berbagai tindakan dan siap menghadapi kesulitan-kesulitan dan menentukan seberapa besar usaha yang dikeluarkan dan seberapa individu bertahan dalam menghadapi rintangan dan pengalaman yang menyakitkan dalam tugas-tugas. Sejalan dengan hasil penelitian tersebut, hasil penelitian yang dilakukan Rahardjo dan Lee (2011) menunjukkan bahwa self-efficacy jelas memainkan peranan penting terhadap kecenderungan prokrastinasi yang dilakukan karyawan. Self-efficacy akan dapat menjadikan individu terhindar dari prokrastinasi dikarenakan adanya keyakinan untuk dapat melakukan suatu tugas tanpa harus terpuruk dengan kesulitan yang muncul dalam suatu tugas.

Berdasarkan hasil uji linearitas pada penelitian ini menunjukkan hasil ada hubungan antara gaya kepemimpinan terhadap prokrastinasi. Hal ini ditunjukkan dari hasil uji regresi dengan ditunjukan nilai sebesar $\mathrm{B}=0,015$. Hasil ini menunjukkan ada hubungan positif antara gaya kepemimpinan terhadap prokrastinasi namun pengaruh yang diberikan sangat kecil. Hal tersebut sesuai dengan pendapat Burn dalam (Marselius dan Rita, 2004) yang menyatakan bahwa bahwa gaya kepemimpinan transformasional mampu menurunkan prokrastinasi kerja bagi karyawan karena kebutuhan karyawan yang lebih tinggi seperti kebutuhan harga diri dan aktualisasi diri terpenuhi. 


\section{Kesimpulan}

Berdasarkan hasil analisis dan pembahasan, maka dapat disimpulkan bahwa terdapat hubungan antara variabel gaya kepemimpinan dan self-efficacy terhadap prokrastinasi. Nilai signifikansi yang ditunjukkan berdasarkan analisis regresi ganda sebesar 0,007 lebih < dari 0,05. dengan koefisien regresi B sebesar 0,015 untuk variabel gaya kepemimpinan ini menunjukkan ada hubungan positif antara gaya kepemimpinan terhadap prokrastinasi namun pengaruh yang diberikan sangat kecil. Selanjutnya koefisien regresi B sebesar -0,543 untuk variabel self-efficacy, hal tersebut menunjukkan bahwa variabel self-efficacy berhubungan negatif dengan prokrastinasi, yaitu semakin tinggi self-efficacy yang dimiliki maka akan semakin rendah prokrastinasi begitu juga sebaliknya semakin rendah self-efficacy yang dimiliki maka akan semakin tinggi prokrastinasi.

\section{Daftar Rujukan}

Azwar, S. (2009). Sikap Manusia, Teori dan Pengukurannya. Jakarta : Pustaka Pelajar.

Bass, M.B and Avolio, J.B. (1990). Developing Transformational Leadership: 1992 and Beyond. Journal of European Industrial Training, Vol. 14 Iss: 5

Bandura, A. (1997). Self Efficacy The Exercise Of Control. New York: W.H. Freeman and Company.

Ferrari, J.R. Johnson, J.L. \& Mc Cown, W.G. (1995). Procrastination and task Avoidance, Theory, Research and Treathment. New York: Plenum Press

Ghufron, M. Nur dan Rini Risnawita S. (2010). Teori-Teori Psikologi, Cetakan I. Yogyakarta: Ar Ruzz Media Group

Kompasiana. (2015). Penyakit Prokrastinasi menunda pekerjaan. http://www.kompasiana.com/hamamburhanudin/penyakit-prokrastinasi-menunda-

pekerjaan_5508848f8133119f14b1e1ec. Diakses 03 Oktober 2019

Kurniawati, Fitria Nur Indah dan Yulianti Dwi Astuti. (2008). Hubungan Antara Prokrastinasi Dan Stres Kerja Pada Karyawan PT. Armada Finance Magelang. http://psychology.uii.ac.id/images/stories/jadwalkuliah/naskahpublikasi-04320163.pdf. Diakses pada tanggal 03 Oktober 2019

Lasmono, H. K., Gunawinata, V. A. R., dan Nanik. (2008). Perfeksionisme, Prokrastinasi Akademik dan Penyelesaian Skripsi Mahasiswa. Anima. Vol. 23. No. 3. Hal. 256-276. Surabaya: Fakultas Psikologi Universitas Surabaya.

Marselius, S.T. \& Rita, A. (2004). Hubungan Antara Persepsi Gaya Kepemimpinan Transformasional dan Transaksional dengan Kepuasan Kerja Karyawan. Jurnal: PSYCHE

Muhid, A. (2008). Hubungan antara Self-Control dan Self Effiacy dengan Kecenderungan Perilaku Prokrastinasi Akademik Mahasiswa. Jurnal Psikologi. Hal. 1-15. Surabaya: Program Studi Psikologi IAIN Sunan Ampel Surabaya

Rahardjo, W., dan Lee, FX, Y. (2011). Prokrastinasi Keterbangkitan dan Menghindar: Kaitannya dengan Efikasi Diri pada Karyawan. Seminar Peran Psikologi dalam Boundaryless Organization: Strategi Mempersiapkan SDM Berkualitas. Hal. 138-13. Fakultas Psikologi Universitas Gunadarma.

Sawitri, D. R. (2009). Pengaruh Status Identitas dan Efikasi Diri Keputusan Karir terhadap Keraguan Mengambil Keputusan Karir pada Mahasiswa Tahun Pertama di Universitas Diponegoro. Jurnal Psikologi Undip. Vol. 5, No. 2, Hal. 1-14. Desember 2009.Semarang: Fakultas Psikologi Universitas Diponegoro.

Steel, Piers. (2007). The Nature Of Procrastination: A Meta-Analytic and Theoretical Review of Quintessential Self-Regulatory Failure. Psychological Bulletin, 133 (1), 65-94

Sugiyono. (2003). Metode Penelitian Bisnis Edisi 1. Bandung: Alfabeta.

Suryabrata, Sumadi. (2005). Pengembangan Alat Ukur Psikologis. Yogyakarta: Andi.

Yukl, G.A. (1998). Leadership in Organizations. Simon \& Schuster (Asia) Pte. Ltd. 